\title{
CEM YILMAZ \\ AND \\ GENRE PAROdY
in TURKISH NATIONAL CINEMA
}

Abstract: Cem

Yilmaz has become nearly synonymous with Turkish comedy through comedies like Arif V 216 (2018). Taking this film as its focus, this article situates Yılmaz among his competitors while tracing his roots in Turkish entertainment by discussing his relationship to midtwentieth-century Yeşilçam and to the meddah storytelling tradition.

Keywords: comedy, cycle, genre, national cinema, parody, Turkey, Yeşilçam
BY

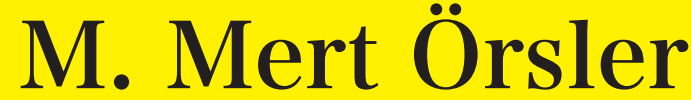
AND

Colleen Kennedy-Karpat

INCE HIS CARICATURE DRAWINGS AND STAND-UP ROUTINES FIRST BROUGHT HIM INTO TURKISH POPULAR CULTURE in the 1990s, Cem Y1lmaz has become nearly synonymous with comedy in Turkey. Y1lmaz's ability to make millions of people laugh has brought him immense public admiration; as of this writing, he has more followers on social media platforms like Twitter than the current president of Turkey. A true multimedia impresario, Y1lmaz has also built a successful filmmaking career as a producer, screenwriter, director, and star. No portrait of Turkish popular culture in the twenty-first century would be complete without Cem Y1lmaz, though Y1lmaz himself would not be who nor where he is in the media pantheon without the waves of production and stardom that set up the media landscape before his arrival. This essay will explore how Y1lmaz has layered his own work over popular entertainment and media histories from both Turkey and Hollywood in order to produce resonant comedy and critique, focusing particularly on his recent film Arif V 216 (Kıvanç Baruönü, 2018), its various intertexts, and its sociopolitical context. 
In the context of Turkish national cinema, Y1lmaz can hardly be called a pioneer of media palimpsests. Turkey has a long and (arguably) celebrated history of appropriation in its filmmaking, starting from the golden age known as Yeşilçam, a name derived from the neighborhood in Istanbul where production companies were headquartered in the midtwentieth century. ${ }^{1}$ During this period of Turkish film production, characters, plot points, sound, and imagery were pulled from foreign films, particularly Hollywood fare, and then retooled for the local industry (Gürata 347). This logic of repetition and recycling stems from a fundamental struggle between high local demand for new films and the lack of financial resources available to meet this demand. Thus, Yeşilçam's output was defined by low-budget "quickies," shot and edited in a matter of months, whose tight production schedules forced filmmakers to curtail or abandon some conventional techniques: for example, filming conversations in a single, unnaturally blocked two-shot rather than a shot/reverse shot sequence (Smith 4). Building on producers' understanding of their local audience's expectations, the quickies capitalize on melodrama, the most popular genre of the time, as well as historical action/adventure and comedy (Erdoğan and Göktürk 536).

Beyond the repetitions inherent to genre, many successful films were also made into series, produced and directed by the same big names and featuring the same box-office stars playing recurring cinematic characters. Comedy series in particular were founded on these practices and spanned the golden age of Yeşilçam. One example is the Turist Ömer series (1964-1973), whose final of seven installments is a remake of Star Trek known in Turkey as Turist Ömer Uzay Yolunda [Ömer the Tourist in Space $]^{2}$ (Dir. Hulki Saner, 1973), which has become a cult object outside Turkey under the informal title of "Turkish Star Trek." As Iain Robert Smith observes,

Copyright (C) 2020 Taylor \& Francis Group, LLC DOI: $10.1080 / 01956051.2020 .1657060$

Color versions of one or more of the figures in the article can be found online at www.tandfonline. com/vjpf.

\section{Genres may surge, recede, and revive over} time, but cycles die out as soon as audiences stop buying into them, which is precisely what happened with these Turkish comedies.

this film reconfigures the world of Star Trek as depicted in the series' first episode, "The Man Trap" (1966), by inserting the comedic title character, "Ömer the Tourist" (Sadri Alışık), into the diegesis. The seriality of films like Turist Ömer and its sequels closely follows what Amanda Ann Klein defines as a film cycle; while in many ways similar to a genre, the film cycle has a limited longevity that depends to a tremendous extent on success at the box office (4). Genres may surge, recede, and revive over time, but cycles die out as soon as audiences stop buying into them, which is precisely what happened with these Turkish comedies.

Several comedy cycles incorporated transnational appropriations in a similar fashion, including two of the longestrunning examples in the history of Turkish cinema. The Cilalt Ibo series (19591972) — named after its central character, "Ibo the Polished," played by Feridun Karakaya-loosely pastiches the Western in its twelfth and final film, Cilal Ibo Teksas Fatihi ("İbo the Polished: Conqueror of Texas," Dir. Mehmet Dinler, 1972). A loose remake of Tootsie (Dir. Sydney Pollack, 1982) was a late entry among the seventeen films (!) that comprise celebrated comic actor Kemal Sunal's Şaban series (1977-1985). ${ }^{3}$ Released under the title Şabaniye (Dir. Kartal Tibet, 1984), the feminine suffix -iye points to the title character passing himself off as a woman. The film Cafer Bey ("Mr. Cafer," Dir. Tunç Başaran, 1970), which launched the Cafer series (1970-1974) that features comedy actor Nejat Uygur, was based on the classic Chaplin film City Lights (1931). These examples show how Yeşilçam expected consistency in performers and filmmakers alike, creating stable (which is not to say restrictive) star images as well as long-running series that return to the same character in film after film. But unlike Hollywood, where film cycles and repeat performances were generally based on local creations, Yeşilçam operated as an adaptation industry based to a significant extent on source materials from outside Turkey, particularly Hollywood (Raw 202). Transnational appropriation blended with a propensity for film cycles to define the industrial spirit of Yeşilçam.

By the 1990s, when Yilmaz began his comedy career, Yeşilçam had been irreversibly hobbled by the 1980 coup d'état and the establishment of national television broadcasting. Film production had fallen well off its peak; still, remnants of its industrial safeguards had been reconfigured for other popular media, and many of these evolutions retain visible traces in contemporary screen production in Turkey. In the twenty-first century, the quickies that were the emblem of Yeşilçam no longer dominate production or exhibition patterns, but Turkish cinema's penchant for series and cycles has continued unabated. If the history of film cycles in Turkish cinema might be traced back to Yeșilçam's various appropriations of American popular cultures - as the cases of Turist Ömer, Şaban, and others suggest - then one might also observe how, around the turn of the millennium, strong comedy cycles with a similarly keen awareness of their international contexts helped the Turkish national film industry to climb out of its decade-long recession. Following Yeşilçam's legacy of appropriation, Cem. Yılmaz playfully updates this mode of transnational media flow for contemporary Turkish audiences, with several key differences marking the transition.

While Yilmaz has also appeared in dramas like Hokkabaz [The Magician] (Dir. Cem Y1lmaz and Ali Taner Baltac1, 2006) and the transnational prestige production The Water Diviner (Dir. Russell 
Crowe, 2014), in Turkey Y1lmaz's bestknown and most financially successful films are burlesque genre parodies, each of which has landed in the all-time top fifty films at the national box office. Similar to globally recognizable Hollywood comedians like Mel Brooks and Mike Myers, Yılmaz commonly portrays more than one character in the same film: protagonists, antagonists, and some supporting roles. The first and still the biggest of Yilmaz's films is G.O.R.A.: Bir Uzay Filmi [G.O.R.A.: A Space Movie] (2004), a genre parody targeting Star Wars (Dir. George Lucas, 1977), The Matrix (Dir. the Wachowskis, 1999) and other science fiction touchstones; its sequel A.R.O.G: Bir Yontmataş Filmi [A.R.O.G: A Prehistoric Film] (2008) blends science fiction with fantasy, drawing on blockbusters like Alien (Dir. Ridley Scott, 1979) and Jurassic Park (Dir. Steven Spielberg, 1993). But the latest component of Y1lmaz's "Arif trilogy"-so named for the central character also featured in G.O.R.A. and A.R.O.G-deviates significantly from the earlier parodies in ways that reveal the industrial logic for cinema in Turkey and beyond. The rest of this essay discusses how and why this third film, Arif V 216, creates a new model of engagement for Turkish cycles and other intertextual multiplicities to incorporate sociocultural and political critique.

\section{Series, Cycles, and Turkish National Cinema}

Multiplicities have defined Turkish cinema since the golden age of Yeşilçam. In coining this term, Amanda Ann Klein and R. Barton Palmer aim to consider and categorize the myriad ways in which popular media rely on what Gérard Genette termed intertexts: adaptations, sequels, series, remakes, and cycles, among other classifications. According to Klein and Palmer, multiplicities introduce a degree of novelty into the already familiar, a strategy that the global film industry has used from its earliest days as a means of generating more surefire profits (8). While standalone films - including Yılmaz Güney's socialist-realist, Palme d'Or winner Yol [The Road] (1982) and, more recently, the arthouse films of festival favorite Nuri Bilge Ceylan-have garnered national and international acclaim, for popular audiences in Turkey, series and cycles form the core of the national film industry. In a market defined by and dependent on multiplicities, the work of Cem Yilmaz opens a window on popular Turkish cinema and media as a whole because of how it manifests the larger patterns inherent in the national sector.

One of the traits that Yilmaz amply illustrates is how, for Turkish audiences, the cultural touchstone of Yeşilçam is simultaneously embraced as history and as a continually relevant part of the present. Marshall McLuhan's famous dictum that "the 'content' of any medium is always another medium" fully applies to Yeşilçam; since the 1990s, national cinema has become national television, and more (McLuhan and Fiore 101). Although there is no reliable way to calculate box-office figures for Yeşilçam classics, since the rise of television, Turkish channels have broadcast these films, particularly on the private channels that have proliferated since Star TV emerged in 1990 as the first private competitor of TRT, the state channel that had held a monopoly and then a near-monopoly over the airwaves since its first telecast in 1968 . The early 2000 s saw the launch of subscription channel Yeşilçam TV, the first channel devoted by design to classic Yeșilçam films. By the mid-2010s, major Yeşilçam-era production companies such as Arzu Film expanded beyond television and began uploading restored and colorized films from their archives to official, studiorun YouTube accounts. Assorted clips from the era's digitized films have thus been kept in circulation on the internet, with many of their generic clichés, characters, and punch lines transformed into widely recognizable memes. This digital proliferation has contributed on the one hand to the international cult status of several films as mentioned above, and also to the continued relevance of Yeşilçam cinema to Turkish audiences, helping familiarize new generations with this golden age. Appearing in his early films and comic TV ads with a pencil mustache and crew cut modeled after 1960s-era Yeşilçam actors, even Cem Yilmaz has visually framed himself as a descendant of Yeşilçam.

In true Yeşilçam spirit, it was a cycle that finally pushed the Turkish cinema out of its post-Yeşilçam slump. In the 1990s, popular nostalgia films gathered enough financial force to drive the national industry out of the doldrums and lay the groundwork for the resurgent Turkish cinema of the twenty-first century. Asuman Suner names Eşklya [The Bandit] (Dir. Yavuz Turgul, 1996) as the cycle's point of origin, a film whose unusually strong box-office returns traced a tantalizing blueprint that other directors used for subsequent hits (306). While by this point Yeşilçam-era production companies like Erler Film had shifted to television, a new generation of filmmakers like Sinan Çetin and Yılmaz Erdoğan reflected the framework of Eşkiya in films like Propaganda (Dir. Sinan Çetin, 1999) and Vizontele (Dir. Y1lmaz Erdoğan and Ömer Faruk Sorak, 2001), a film that also features Cem Yilmaz in a comic supporting role that profoundly contributed to his national popularity. Despite the fact that glamorizing the Turkish past or valorizing it over the present might well give these nostalgia films strong political meanings or gesture toward a critical stance, Suner argues that the cycle's "ideological blind spot" tames its social criticism-as is the case in Çetin's film (308). Sharing the running subtext of nostalgia for the 
The end of the 2000s saw the decline of the Hollywood parody cycle.... [B]y 2010 such films could not sustain audience interest ...

county's past, the imagery of provincial landscapes, and the themes of innocence and harmony of traditional community life with Turgul's film, Vizontele nonetheless found similar box-office success (Suner 309).

Starting soon after and running concurrent with the popular nostalgia film cycle came a different cycle of Hollywood parodies, and it was this one that heralded the rise of Cem Yilmaz. Seen by many as following in the footsteps of comic actor Sadri Alışık, star of the Turist Ömer series, Y1lmaz quickly became a trendsetter in popular Turkish cinema, producing some of the best-known "Turkish blockbusters" (Smith 11). Taking G.O.R.A. as the originary text, the Hollywood parodies - which were produced by a few different Turkish companies - all aimed to replicate its financial success; G.O.R.A. brought in roughly $\$ 18$ million in Turkey, ${ }^{4}$ breaking the box-office record that had been briefly held by Vizontele.

Yllmaz built further on the momentum of the parody cycle by making a sequel: A.R.O.G was released four years after G.O.R.A., though it adopted a different genre framework for its parody. Following Yilmaz, Kutsal Damacana ("Holy Carboy," Dir. Kamil Aydın and Ahmet Y1lmaz, 2007) targets Hollywood horror, primarily The Exorcist (Dir. William Friedkin, 1973), and features comedy actor Şafak Sezer, who also costarred with Yilmaz in G.O.R.A. Kutsal Damacana's codirector and scenarist Ahmet Yilmaz (who has no family relationship to Cem Yilmaz) is also a caricaturist friend of Cem Yilmaz from his time at Leman, one of the country's leading satirical magazines and the publication where Cem Yilmaz's drawings first appeared. Known as the person who encouraged Cem Y1lmaz's early humor on the page and stage, Ahmet Yilmaz was also a second assistant director on A.R.O.G. While Kutsal Damacana's intake could not match G.O.R.A.'s unprec- edented success, it was still one of Turkey's highest-grossing films of 2007, earning roughly $\$ 5$ million.

The end of the 2000s saw the decline of the Hollywood parody cycle. Kutsal Damacana's initial success led to its first sequel, Kutsal Damacana 2: Itmen (Dir. Korhan Bozkurt, 2010), which featured Şafak Sezer once again in a parody of werewolf films and the Rocky series (1976-2006). ${ }^{5}$ Yet by 2010, such films could not sustain audience interest; a parody of the Saw horror films (2004 2017), Destere ("Saw," Dir. Ahmet Uygun and Gürcan Yurt, 2008), brought in just $\$ 1.2$ million; three years later, the second Kutsal Damacana sequel, a parody of vampire films titled Kutsal Damacana 3: Dracoola (Dir. Korhan Bozkurt, 2011), grossed even less than Destere, barely crossing $\$ 1$ million. These films thus announced the end of the parody cycle's financial viability, although Cem Yilmaz tried to keep it going with his Western spoof Yahşi Batı [Mild West] (2010), whose comedy stems primarily from the localization of many genre-specific elements. But even this film brought in less than its predecessors, and the next Yilmaz comedy, Ali Baba ve 7 Cüceler [Ali Baba and the 7 Dwarfs] (2015)—which targets Hollywood action/adventure blockbusters including Predator (Dir. John McTiernan, 1987) and The Hunger Games (Dir. Gary Ross, 2012)_-grossed less than $\$ 7.5$ million and remains one of his least financially successful films. Meanwhile, Turkish comedies such as comic actor Ata Demirer's Eyvah Eyvah [Oh Dear] (Dir. Hakan Algül, 2010) and Recep Ivedik, an ongoing series whose first three films (2008, 2009, and 2010) were these genre parodies' direct competition, gained enough momentum to push Yilmaz from his box-office throne.

This decline in performance indicates a need for innovation in the form, and a full decade after A.R.O.G, Cem Yilmaz dialed down his reliance on Hollywood to find different sources of intertextual meaning for Arif V 216. Many elements of this film still point to transnational media flow, but it prioritizes attention to specifically national film histories, particularly Yeşilçam. Pastiche combines with parody in Arif $V$ 216, which is not a thoroughly resistant or overtly politicized sendup of peak Yeşilçamas is the case in Ertem Eğilmez's Arabesk [Arabesque] (1988)_but the film nevertheless combines recognizable elements of bygone Turkish cycles with current and classic Hollywood blockbusters. Manifesting an eclectic intertextual realm, Y1lmaz articulates his deviance from G.O.R.A. and the Hollywood parody cycle of the 2000 s through innovative approaches to pastiche and intertextual referencing. As a multifaceted example of multiplicity in Turkish popular cinema, Arif V 216 also engages the subtext of nostalgia by connecting it to a sociopolitical critique of the present. For Suner, one of the most recognizable aspects of the popular nostalgia cycle in the 1990s is its "mild left-wing oppositional critique of the transformation of Turkish society" (310). Using similar appeals to nostalgia, Arif V 216 builds a Yeşilçam pastiche through moments of direct remediation interspersed with cross-cultural intertexts that undergird the film's political critique.

\section{Yeşilçam Pastiche, Nostalgia, and the Turkish National Past}

The vivid intertexts of Yilmaz's film, conveyed through semiotic codes of pastiche and parody, are crucial to the underlying themes, critique(s), and meanings in Arif $V 216$. As a sequel to G.O.R.A. and A.R.O.G, the film extends the adventure of the series protagonists Arif (Cem Y1lmaz) and the robot $216^{6}$ (Ozan Güven). In addition to the film's allusions to Hollywood, an aesthetic of remediation enhances the film's pastiche in sequences that are aesthetically and thematically distinct from other intertextual expressions in their selective, critical framing of Yeşilçam melodrama. Besides the references to the country's past and the common aesthetic characteristics pertaining to the genre, Arif $V$ 216 focuses on some of the narrative clichés of Yeşilçam that convey communal values such as benevolence, 


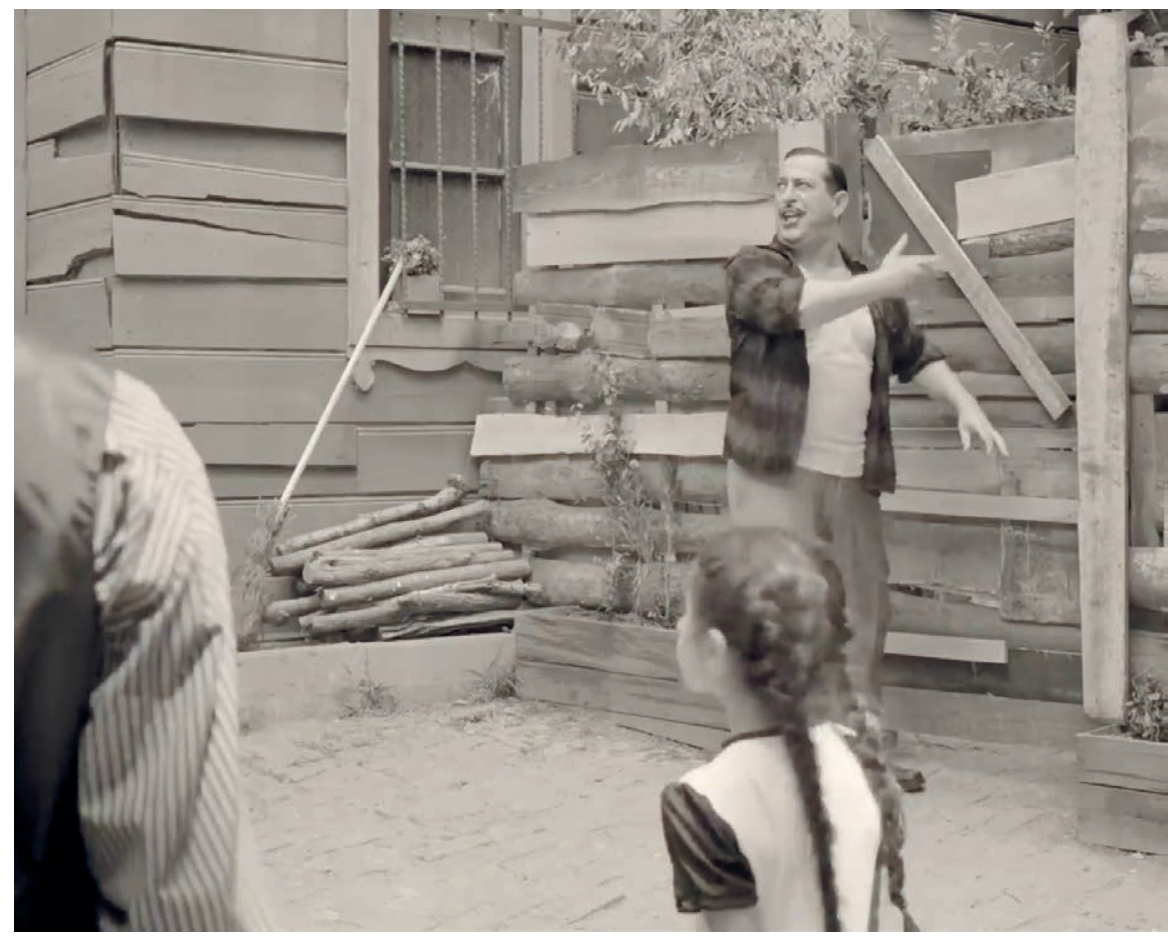

Figure 1. Arif V 216 (Dir. Kıvanç Baruönü, 2018). Arif (Cem Y1lmaz) stands in front of a traditional wooden house in Istanbul, talking to neighborhood residents.

friendliness, and solidarity. The pastiche thereby designates Yeşilçam (and its attendant national histories) as "good," even if its narrative and cinematic conventions might hide insidious motives behind its ostensibly naïve or innocuous style. The result is a nostalgic pastiche that underscores longing for the past while yearning for a better present.

Arif V 216's pastiche sequences cover almost the entire second act of the film, but the first clear pastiche offers enough exposition to unpack the film's strategy in using it (Figure 1). It begins with Arif and 216 suddenly transported into 1969 Turkey, a significant date that indicates, first, that the worldwide protests of 1968 had happened but had not yet been fully reflected in Turkey, and second, that the "golden years" of Yeşilçam were underway. The reconstruction of the Yeşilçam aesthetic includes a series of juxtapositions where monochrome shots of characters coded as lower class are synchronized with the classical Turkish music of the period to evoke the era's family melodramas. The narrative effect is to suggest that the characters have been teleported not into the actual past, but rather into a hypothetical Yeşilçam film.

Y1lmaz's film benefits from all three techniques that Richard Dyer formulates as the main methods of pastiche: deformation, likeness, and discrepancy (Dyer 52). The sequence described above particularly illustrates likeness and discrepancy. What Dyer defines as discrepancy is the "interruption of extraneous elements, most often jokes and witticisms" that would be unexpected in source texts of the pastiche (58). In other words, discrepancy uses a sense of absurdity to signal to an attentive audience that the text is, in fact, a pastiche. In this sequence of Arif V 216, the discrepant in-jokes do not precisely contribute to the meanings of its pastiche but they invite the viewer to comprehend the text as pastiche. One such discrepancy is a cross-cultural intertext: Y1lmaz's character, Arif, travels through time wearing only his underwear in reference to the Terminator franchise, specifically the originary moment in The Terminator (Dir. James Cameron, 1984) when Arnold Schwarzenegger's character travels naked into the past. The sequence transforms this iconic Hollywood moment, even if this allusion is incongruous with the Yeşilçam aesthetics that dominate the pastiche. The sequence's likeness to Yeşilçam sets up the contrast that further marks the discrepancies of the cross-cultural intertexts. The blackand-white, sepia-tinted cinematography of the early Yeşilçam pastiche evokes the clichéd setting of mid-century Istanbul, whose residents/characters are defined by their costumes, hairstyles, and makeup. Such attention to the daily practices of the past, such as swimming in the Bosporus, exists in opposition to Arif's sci-fi-styled time travel. Integrating a discrepant cross-cultural reference into the Yeşilçam aesthetic thus reinforces the film's pastiche by its very departure from its nostalgic remediation.

Intertextual references with little or indirect relevance to the narrative progression offer nonnarrative pleasures that multiplicities are particularly suited to offer. As Stuart Henderson observes of such pleasures in movie sequels, "you don't need to get the reference, but doing so will give you a fuller, more rewarding viewing experience" (130). Arif's allusive transportation to the past neither excessively limits nor directly contributes to the narrative logic. Rather, appropriating Hollywood style and pointing to one of its globally known blockbuster series are an end in themselves, an amusing diversion and not a necessity of narration. Missing this intertext would neither change the narrative logic of Arif V 216 nor alter the subtext of the pastiche such a reference interrupts. Although Yilmaz's ear-

\section{The reconstruction of the Yeşilçam aesthetic} includes a series of juxtapositions where monochrome shots of characters coded as lower class are synchronized with the classical Turkish music of the period to evoke the era's family melodramas. 
lier burlesque genre parodies prioritize nonnarrative pleasures, in Henderson's sense, in Arif $V 216$ several intertexts are explicitly related to parodic purposes; the nationally specific inflection of Yeşilçam means that these references take on different connotations than before.

If discrepancy describes how Yilmaz integrates cross-cultural intertexts into his parody, it is the likeness of the Yeşilçam pastiche that highlights the nostalgia of Arif V 216. For Dyer, likeness brings "various elements together," so that the "pastiche is very like that which it pastiches," but is also inherently selective in its affectionate mimicry (54). Yilmaz's film emulates the Yeşilçam melodramas associated with the country's past; yet, Arif V 216 is neither identical to nor indistinguishable from these iconic films. Based on specific cultural knowledge, this stylized intertextual articulation relies on audience familiarity with conventions, sources, and texts from a combination of Turkish and Hollywood hypotexts (Newman 144). When they arrive in this place, Arif and 216 start chasing some prankish kids, who lead them to a traditional wooden house whose residents are happy to host them. Arif's ridicule of the naïveté of the neighborhood inhabitants, their regional intonations, and the seemingly excessive kindness he encounters contrasts with 216, who expresses only admiration, saying "There is peace here." This sequence, which starts out in black and white before turning to color, relies on wide-angle and medium shots in imitation of the dominant cinematographic practice of Yeşilçam. The art direction, especially costumes and makeup embellished in 1960s fashion, helps Arif V 216 reconstruct a familiar mise-en-scène, and the performers deploy a highly codified, performative acting style that characterizes the genre-all characteristics that manifest most evidently in Pembeşeker (Seda Bakan). In a metacinematic aside, Arif notes the resemblance to Yeşilçam: "We've watched these movies one too many times."

Representation of the home offers another likeness to Yeşilçam. The traditional wooden houses in working-class and impoverished Istanbul districts

\section{Arif V 216's vision of twenty-first-century Turkey argues that hate, egoism, and asperity have displaced the kindness and community- building spirit of the I960s and I970s ...}

are shown against a backdrop of nondiegetic, traditional Turkish music that also signals a connection to Yeşilçam. As in Turkish melodramas, the neighborhood depicts a friendly, benevolent, and sincere community where the residents live in harmony and solidarity (Dönmez-Colin 197). The home where Arif and 216 end up, Tonos Hayri's house, is a cheerful haven for a group of people who claim to be fundraising for Pembeşeker to undergo surgery that will cure her blindness. The characterization of Pembeşeker as a blind woman holds intertextual significance, referring particularly to Memduh Ün's Ü̧̧ Arkadaş [Three Friends] (1972, a remake of an eponymous 1958 melodrama). In Arif $V$ 216, Tonos, his family, and friends are almost stand-ins for the characters raising money in $\ddot{U}_{c}$ Arkadaş, and Pembeşeker - with her plaited brown hair and one-dimensional (or stereotypi$\mathrm{cal}^{7}$ ) characterization as a naïve young Turkish woman - alludes even more precisely to Hülya Koçyiğit's blind young woman awaiting surgery in Ün's melodrama. Beyond the sheer allusive pleasure of the reference, it also helps Arif $V$ 216 emphasize themes such as friendliness, collectiveness, and solidarity.

But even this heartwarming setup turns out to be an illusion; Arif discovers that the house and its people have adopted these identities as part of a "scientific experiment" based on the question of whether "good people" exist in the world. The premise is admittedly far-fetched (to say nothing of its "science"!), but this plot twist reveals a canny, self-reflective layer of Arif $V$ 216 's pastiche, pointing to the artificiality and constructedness of Yeşilçam genre clichés even as it proclaims their nostalgic value.

Such a pastiche offers examples of what Svetlana Boym calls restorative nostalgia and reflective nostalgia; while
Tonos Hayri's house signals the former, the latter plays out in the Arif-216 conflict. Restorative nostalgia "builds on the sense of loss of community and cohesion" in a lost (or imagined) homeland by attempting to reconstruct that place and time in ways that are at best partial and at worst delusional, whereas the reflective one-often ironic - reveals the fact that reflection and longing are "not opposed to one another" (Boym 41, 49). Through pastiche, the nostalgic metaphor of Tonos Hayri's house constructs a textual amalgam that signifies the "lost home" of mid-century Turkey and contrasts this inaccessible realm with a problematic present. Arif V 216's vision of twenty-first-century Turkey argues that hate, egoism, and asperity have displaced the kindness and communitybuilding spirit of the 1960s and 1970s, and Tonos Hayri's house demonstrates what the present moment "lacks" or, at least, fails to express. For Arif and 216, the house is not only a place for physical accommodation, but also an embodiment of ideologies that (allegedly) no longer hold sway in the 2000s. Rebuilding the lost home becomes a literal act through pastiche, and this intertextual recreation is infused with nostalgia for bygone, nationally specific modes of cinematic storytelling. The character 216, whose affection for Yeşilçam classics was first established in G.O.R.A., is quick to take this restorative line of nostalgia at face value, but the irony involved in Cem Y1lmaz's character aligns instead with reflective nostalgia. Alongside his visible, often exaggerated resemblance to golden-age actors, through the narrative Arif becomes privy to the artificiality of this constructed past and thus never displays an uncritical remembrance. This conflicting perspective on nostalgia foreshadows the interpersonal conflict that pits the characters against one another later in the film. 


\section{Yilmaz's film frames the country's past} through Yeşilçam conventions and ideologies coded as decent yet inaccessible in an

\section{apocalyptic present.}

Arif $V 216$ further specifies the nostalgic past and the reimagined present through remediation aesthetics that create what Dan Harries calls "mendacious intertextuality," which presents a text-within-a-text with a different modal aesthetic from its surroundings that presents a distinct "text" that exists only in the framework of the supertext (28). This is not unrelated to Jay David Bolter and Richard Grusin's concept of remediation, which refers to the "representation of one medium in another" (45); still, Harries's emphasis on its mendacity aligns it more effectively with the strategies that Dyer sees as endemic to pastiche. In one example of a mendacious intertext, one sequence evokes a TV commercial timed in the film for maximum irony: a widespread convention of Turkish theatrical exhibition is a ten-minute intermission roughly halfway through the film, meaning that this fake commercial would be situated directly alongside actual advertisements that would be played during the break. Styled to resemble ads that aired in the 1970s on TRT (the sole available channel at the time), the mendacious ad shows the character 216 promoting a toy version of himself. The remediated style integrates 216 in a warm home environment, as if the robot were a natural part of a nuclear family. The cheerful, non-diegetic background music and offscreen narration point toward trends in television advertising of the 1970s, and the slogan "Can we be friends?" further highlights the ideological thrust of the film's overarching pastiche. Thus, remediation aesthetics highlight the positivity that the pastiche sequences associate with the past while simultaneously emphasizing its constructedness.

\section{Meddah, Parody, and Business (as Usual?)}

The pastiche at the center of Arif $V$ 216 serves as the foundation for a par- ody that connects the film's critique of social transformation to a sociopolitical commentary of present-day Turkey. Y1lmaz's film frames the country's past through Yeşilçam conventions and ideologies coded as decent yet inaccessible in an apocalyptic present. The critical target of Yilmaz's parody in Arif $V$ 216 is ultimately contemporary Turkey, specifically Recep Tayyip Erdoğan's Turkey. Dialogue throughout the film comments (obliquely if not overtly) on Turkish politics; an illustrative line is Arif's comment to a group of foreign agents: "Komşularla sifir sorun!" translated as "Zero problems with neighbors," a well-known foreign policy slogan of AK Party officials and Erdoğan himself. Visually, the film constructs a vision of a totalitarian regime headquartered in contemporary Istanbul, but Yilmaz's parody does not engage in a harshly resistant criticism of the country's contemporary politics; the parody, and thus the criticism, lies in the contrast between past and present, both of which are highly codified through intertexts. Whereas the pastiche of Yeşilçam depicts utopian positivity, the present is a dictatorial dystopia that nevertheless appropriates representations of the past to suit its own ends. By portraying an apocalyptic version of the present, the parody connects the sociohistorical critique of pastiche to a political one, which in turn contributes to Yllmaz's meddah aura.

Arif V 216 is fully open to interpretation as a genre-savvy parody - which is, after all, Yllmaz's trademark-yet the domination of Yeşilçam suggests that this time, the parody is more local. But this does not preclude meaningful engagement with Hollywood, and indeed, the strongest connections to Hollywood serve a specifically national critique. A five-minute sequence, situated roughly at the film's midpoint, leaves Yeşilçam behind as Arif and Pembeșeker are transported to a version of the present in which the formerly mild-mannered 216 has been renamed Pertev and become a cold-hearted villain (see Figure 2). This confrontation between Arif and 216 is foreshadowed in the film's title, where a play on words has the " $V$ " referring both to the Turkish word ve, meaning "and," as well as the English abbreviation for versus - a linguistic manifestation of Y1lmaz's cross-cultural vernacular. Emulating the gloomy palettes of iconic films like Blade Runner (Dir. Ridley Scott, 1982), this sequence also echoes Blade Runner's dichotomy between human and nonhuman but figures a robot as the oppressor and humans as the oppressed. This conflict results in a sharp decrease in Istanbul's human population, as Arif soon realizes: "Everywhere is full of robots!" Still, the lack of immediate clarity regarding the robot/human divide opens up possibilities for parodic misdirection (Harries 38). When Arif strikes up a chat with a kebab seller, the seller responds with "Aleykümselam," a religious salutation among Muslims, and wears a cap used by observant Turks during their ritual prayers. In contemporary Turkey, both of these would signal a pious member of the conservative majority, but in the diegesis this presumption serves as a misdirection: while Arif assumes that the seller is an ordinary human, he is revealed to be a robot. Aside from illustrating the ubiquity of robots in this alternative present, Arif's encounter also aligns the robot oppressors in 216/Pertev's Istanbul with the conservative majority that holds actual political power in contemporary Turkey. Through parodic misdirection, this sequence codes such rote, religious behavior as a nonhuman and potentially oppressive impulse. In drawing on genre conventions of dystopian films, this sequence in Arif $V 216$ offers a sharp contrast between contemporary Istanbul and the utopian view of Turkey shown in the Yeşilçam pastiche. In addition to misdirection, it also uses mendacious intertextuality and exaggeration as parodic devices that point to Erdogan's Turkey as the target of the film's critique. A TV news broadcast within the diegesis shows the ruler 216/Pertev being addressed as "büyük 




Figure 2. Arif V 216 (Dir. Kıvanç Baruönü, 2018). Arif (Cem Yılmaz) and Pembeşeker (Seda Bakan) enter a dystopic version of present-day Istanbul that includes a billboard with an image of 216/Pertev (Ozan Güven).

patron" ("great patron," or more colloquially, "big boss"). These words frame 216/Pertev as both a despotic leader and a respected businessman, pointing to a corrupt system in which corporations and the government are malevolently intertwined.

Intrusive police drones and the robotic hostility of the officers who take Arif to see 216 also suggest a totalitarian police state in thrall to the corporatized structures of power. The collapse of any meaningful distinction between capitalist enterprise and political authority is not only a common generic element in Hollywood dystopias like Blade Runner and Paul Verhoeven's RoboCop (1987) but also a key criticism of the ruling AK Party's modus operandi ${ }^{8}$ since their rise to power in 2002. Still, the genre discourse that shapes this sequence exaggerates these elements of Turkish society so that the film's criticism is clearly legible, yet broad enough not to pinpoint a sole cause of this social discord. Not all of the Hollywood references underscore the film's sociopolitical critique. One example of an intertext that offers nonnarrative pleasure without advancing the film's politics is the visual evocation of Watchmen (Dir. Zack Snyder, 2009), another dystopian film. In his confrontation with Pertev, Arif meets a fate similar to the Comedian's (Jeffrey Dean Morgan) in Watchmen: first Arif is thrown on a table, breaking its glass; then, when Pertev throws Arif through the skyscraper's window, slow-motion cinematography captures Arif and the broken glass in a visual nod to Snyder's film. Unlike Arif V 216's structural reference to Blade Runner, which frames the human/nonhuman conflict that drives the plot, visual gags referencing Hollywood films offer examples of

\section{Intrusive police drones and the robotic} hostility of the officers who take Arif to see 216 also suggest a totalitarian police state in thrall to the corporatized structures of power. 
what Harries calls extraneous inclusion, meaning the introduction of visual, narrative, or other elements that relate neither to the target of the parody nor to the text's general logonomic system (39). This is similar to Dyer's notion of discrepancy in pastiche, but parody is more consistent in using this strategy as a source of humor. Yilmaz's films are full of such gags; another example from Arif $V 216$ shows a woman exhorting Arif to "Think of the children!" while said children are twin girls dressed like characters from The Shining (Dir. Stanley Kubrick, 1980). Extraneous inclusions like these reinforce the parody, but they do not necessarily frame the film's social commentary.

Arif $V 216$ uses parodic strategies both to shape its critique and to provide largely apolitical moments of comic relief; still, on the whole, the film remains an exceptionally political work in Cem Yilmaz's oeuvre. Even the choice to wax nostalgic about Yeşilçam is in itself a political choice, as it refuses a more prevalent current of nostalgia that Chien Yang Erdem calls Ottomentality, a trend that echoes the AK Party's neo-Ottomanism and which has produced several films and TV series, including Muhteşem Yüzyll (Magnificent Century, 2011-2014), Diriliş: Ertuğrul (Resurrection: Ertugrul, 2014-2019), and Fetih 1453 [Conquest 1453] (Dir. Fatih Aksoy, 2012) (Erdem 710). But even without making this more distant period in Turkish history the backdrop for his parody, Yılmaz's understanding of representation and performance has its roots in a similarly long-standing, local tradition: the meddah.

Arif V 216 brings renewed strength to Y1lmaz's meddah reputation, which has long been discussed as part of his popular image (Cankara 339). Meddah is both an informal title for a person and a storytelling tradition in Turkish theater. Historically an exclusively male pursuit, meddahs are characterized by their humor and penchant for integrating sociopolitical criticism into their live performances, which generally take place in coffeehouses at night. ${ }^{9}$ Y1lmaz's standup shows in particular blend a contemporary Western stage format with Anatolian traditions; stand-up and meddah are both designed to be one-man shows

Arif $V 216$ is certainly a genre film, but the complexity of its sets, effects, and other trappings of the form are blended with a deftly conveyed critique that reaffirms its creator's roots in the meddah tradition ...

based on mimicry and improvisation, with limited use of costumes, makeup, music, and props. Y1lmaz has brought such shows to the stage and to the big screen; thanks to its wide theatrical release, his stand-up show CM101MMXI Fundamentals (Dir. Murat Dündar, 2013) brought in audiences across Turkey and more than $\$ 20$ million at the box office. Despite this huge financial success, rather than churning out more cheaply produced, pared-down standup, Yilmaz has balanced stage comedy with a brand of filmmaking that requires unusually high budgets to create the artifice needed to evoke Hollywood's genre films. And Arif V 216 is certainly a genre film, but the complexity of its sets, effects, and other trappings of the form are blended with a deftly conveyed critique that reaffirms its creator's roots in the meddah tradition, as key figures in meddah stagecraft incorporated sociopolitical criticisms in their shows (Cankara 341).

In addition to social critique, distanciation techniques such as playfully breaking the fourth wall and a climactic tirade are also part of the meddah tradition (Cankara 339). These moments recur throughout the Arif trilogy, and Turkish audiences' familiarity with these metacinematic devices cultivates mutual awareness between the performer and the audience, who are thereby encouraged to be conscious not only of the entertainment experience, but also their role in it. One playful example of breaking the fourth wall in Arif V 216 is a diegetic signal to start the ten-minute intermission roughly halfway through the film, timed to appear immediately before the appearance of actual commercials that would play in theaters during the intermission mentioned above. The signal appears when Arif and Pembeşeker first take in the apocalyptic vision of Istanbul, as the camera cuts to a wide shot that reveals a billboard on which is written the word ara (break) - a break that would then be followed by the fake advertisement described above.

How does Yilmaz's meddah aura relate to Turkish cinema's industrial logic? The answer lies in legal and social changes that have generated renewed interest and investment in Turkey's film industry since 2005. That year saw Turkey's reestablishment of public production support through Cinema Law 5224, after which the country's annual production-which had numbered around twenty films per year-increased sharply, reaching more than eighty films in 2013 (Kanzler 26). As the law bolstered national filmmaking, audiences greeted this revival with great interest, ${ }^{10}$ and throughout the country cinema chains like Cinemaximum opened state-of-the-art multiplexes in shopping malls (most of which were themselves newly constructed) to meet the increasing demand for screenings. While the old, largely independent theatres of Yeşilçam had closed down one by one, since 2000 the mall-centered cinema has become increasingly integrated into consumerist society, signaling a profitmaking opportunity for the entertainment sector. This new law also encouraged many in the comedy business to move into film; in 2008, comic actor Şahan Gökbakar brought a character from his TV sketch show Dikkat Şahan Çıkabilir ("Caution: Şahan May Break Out," 2005-2006) to the big screen in Recep Ivedik, which grossed over \$24 million and broke box-office records previously held by Y1lmaz's G.O.R.A. and A.R.O.G. Subsequent installments in the ongoing Recep Ivedik series have continued to outperform Yilmaz's comedies, suggesting that Y1lmaz's effort to 
bolster his meddah image in Arif V 216 can be understood as a timely attempt to differentiate himself and his product from market competitors. While in many respects, Y1lmaz's films are not conventional examples of meddah performance, the fact remains that comic film actors like Gökbakar-who has not showcased his talent on the stage, nor used his performance platform for political criticism - cannot make any sort of claim to the meddah tradition.

The fact that Yilmaz writes, produces, and frequently codirects his films also highlights his unique role in Turkish media. Attentive audiences can detect material from his stand-up shows that has been repurposed for his films, meaning that Yilmaz may be understood, among other things, as a self-adapter. As the widely recognized creative force behind humor expressed through page, stage, and screen, considering Yilmaz as a self-adapter adds another layer of significance to his multimedia oeuvre in how his work elaborates or effaces different intertextual connections (Kennedy-Karpat 68). For instance, in the post-credit sequence in Arif $V 216$, the robot 216 meets another robot, 232, which is an upgraded robot physically coded as feminine. ${ }^{11}$ The encounter thus references a locally famous joke from CM101MMXI Fundamentals: "Woman is the upgraded version of man." Borrowing from his earlier stand-up shows to create self-referential intertexts in his films, Cem Yilmaz rewards audiences who take a completist approach to his comedy.

Cem Yilmaz thus stands alone in his ability to interweave Turkish traditions and histories with the cinematic language of Hollywood blockbusters. In a national industry with a long-standing reliance on multiplicities, Arif $V 216$ throws a spotlight on the innovations that force film cycles to evolve, using creativity that draws on aesthetic and textual strategies in addition to industrial concerns. Blending nostalgia, which is a recognizable element of an earlier national cycle, with the Hollywood parody cycle that he launched and, in many ways perfected, Arif V 216 illustrates how an industry can blend new and old to extend audience interest. Us- ing pastiche, parody, and cross-cultural intertexts, Arif V 216 introduces themes and critiques that depart from the earlier films in the series. In moving beyond these two fish-out-of-water comedies, Y1lmaz pushes Arif V 216 into more urgently political territory, but without naming or blaming specific factors that provoked its negative outlook. Despite the unusually long time between films in the series and Y1lmaz's string of box office disappointments released in the interim, Arif V 216 earned roughly \$14 million and showed that Turkish audiences would still turn out for the adventures of a cinematic meddah.

\section{ACKNOWLEDGMENT}

The authors extend their thanks to Ahmet Gürata for his insightful comments on an earlier draft of this essay.

\section{NOTES}

1. The late 1960s and 1970s are known as the "golden years" of popular Turkish cinema primarily due to their sheer rate of production; at the time, Yeşilçam was the third most productive film industry in the world, with 229 films produced in 1966 alone. See Smith and Suner.

2. All translations from Turkish to English are M. Mert Örsler's, except where English titles are available on IMDb as of this writing, in which case the translated title is in brackets. All original translations are literal and signaled by the use of quotation marks inside parentheses.

3. Although Kemal Sunal has never been particularly known for his television work, his Şaban character continued on TV postYeşilçam in Şaban Askerde ("Şaban in the Army," 1993-1994) and Şaban ile Şirin ("Şaban and Şirin," 1996-1997). While he continued to perform, Sunal also earned BA and MA degrees in cinema and television at Marmara University. His masters thesisa pioneering example of "mesearch" that he defended in 1998 - is entitled "Sinema ve Televizyonda Kemal Sunal Güldürüsü" ("The Comedy of Kemal Sunal in Cinema and on Television").

4. All earnings figures are taken from the Box Office Mojo website.

5. Ryan Coogler's Creed (2015) and its sequel Creed II (Dir. Steven Caple, Jr., 2018) are also part of the Rocky multiplicity, though arguably not part of the series proper. See Henderson, especially chapters 1 and 2, for a further discussion of series, sequels, and spin-offs.

6. The number 216 refers to the Asian-side telephone area code for Istanbul. This reference sets up a joke for another character's name - see note 11 .
7. In addition to the overt sexism in Y1lmaz's comedies, representation of women in popular Turkish cinema, especially in Yeşilçam, has always been problematic. Despite changes in the industrial logic, popular films continue to objectify women and reflect patriarchal control over intellectual property. There are a few exceptions, however, in the country's auteur cinema; for more on gender in Turkish cinema, see Atakav.

8. The close relationship between business and government is a publicly known phenomenon in the country. See Buğra and Savaşkan.

9. Meddahs were particularly popular between the sixteenth and nineteenth centuries, but they disappeared around the midtwentieth century, at least from the coffeehouses. Associated directly with the Turkish traditional plays like meddah, İsmail Hakkı Dümbüllü was also an early comic performer in films. The Dümbüllü film series (1948-1954), whose title character bears the actor's real surname, includes another early example of American popular culture appropriation: Dümbüllü Tarzan (Muharrem Gürses, 1954). Today, Dümbüllü’s kavuk (a traditional cap similar to a fez) is regarded as an important icon of Turkish theater. See Halman and Warner, and Kafadar, for an early history of the "Istanbul meddahs."

10. Recovering from the severe effects of the 2000-2001 banking crisis in Turkey, the early and mid-2010s saw general economic growth that especially affected the middle class, which found itself with more money to spend on leisure activities like moviegoing. Financial recovery and political stability encouraged foreign investment, including in the film industry and its distribution. Foreign investment also contributed to a nationwide construction boom that brought a great number of malls and their movie houses into physical existence. See Öz and Özkaracalar.

11. Besides the "upgrade" joke, the name 232 is also a reference to the telephone area code for İzmir, which refers to the Turkish stereotype "İzmir'in kizları güzel olur," which translates as "girls from İzmir are beautiful." See note 6 .

\section{WORKS CITED}

Ali Baba ve 7 Cüceler [Ali Baba and the 7 Dwarfs]. Dir. Cem Y1lmaz. Turkey. 2015. Alien. Dir. Ridley Scott. UK/USA. 1979.

Arabesk. Dir. Ertem Eğilmez. Turkey. 1988. Arif V 216. Dir. Kıvanç Baruönü. Turkey. 2018

A.R.O.G: Bir Yontmataş Filmi [A.R.O.G.: A Prehistoric Film]. Dir. Ali Taner Baltac1 and Cem Y1lmaz. Turkey. 2008.

Atakav, Eylem. Women and Turkish Cinema: Gender Politics, Cultural Identity and Representation. Routledge, 2012.

Baruönü, K1vanç, director. See Arif V 216. Netflix, 19 May 2018, twww.netflix.com/ search?q=Arif $\% 20 \mathrm{~V} \% 20216$.

Blade Runner. Dir. Ridley Scott. USA/Hong Kong. 1982. 
Bolter, Jay David, and Richard A. Grusin. Remediation: Understanding New Media. MIT P, 2000.

Box Office Mojo. BoxOfficeMojo.com.

Boym, Svetlana. The Future of Nostalgia. Basic Books, 2001.

Buğra, Ayşe, and Osman Savaşkan. New Capitalism in Turkey: The Relationship between Politics, Religion and Business. Edward Elgar, 2014.

Cafer Bey. Dir. Tunç Başaran. Turkey. 1970.

Cankara, Murat. "Cem Yllmaz Bir 'Modern Meddah' Midır?" ("Is Cem Yilmaz a 'Modern Meddah'?") Mitten Meddaha Türk Halk Anlatılarl: Uluslararası Sempozyum Bildirileri (Turkish Folk Narratives from Myth to Meddah: International Symposium Papers), edited by M. Öcal Oğuz and Tuba Saltık Özkan, Gazi Üniversitesi, 2006.

Cilalı İbo Teksas Fatihi. Dir. Mehmet Dinler. Turkey. 1972.

City Lights. Dir. Charles Chaplin. USA. 1931.

CM101MMXI Fundamentals. Dir. Murat Dündar. Turkey. 2013.

Destere. Dir. Ahmet Uygun and Gürcan Yurt. Turkey. 2008

Dönmez-Colin, Gönül. The Routledge Dictionary of Turkish Cinema. Routledge, 2013.

Dümbüllü Tarzan. Dir. Muharrem Gürses. Turkey. 1954.

Dyer, Richard. Pastiche. Routledge, 2007.

Erdem, Chien Yang. "Ottomentality: Neoliberal Governance of Culture and Neo-Ottoman Management of Diversity." Turkish Studies, vol. 18, no.4 (2017), pp. 710-28.

Erdoğan, Nezih, and Deniz Göktürk. "Turkish Cinema." Companion Encyclopaedia of Middle Eastern and North African Film, edited by Oliver Leaman, Routledge, 2001, pp. 533-73.

Eşkıya [The Bandit]. Dir. Yavuz Turgul. Turkey. 1996.

The Exorcist. Dir. William Friedkin. USA. 1973.

Eyvah Eyvah [Oh Dear]. Dir. Hakan Akgül. Turkey. 2010.

Fetih 1453 [Conquest 1453]. Dir. Fatih Aksoy. Turkey. 2012.

Genette, Gérard. Palimpsests: Literature in the Second Degree (Stages). Translated by Channa Newman and Claude Doubinsky. Lincoln: U of Nebraska P. 1997.

G.O.R.A.: Bir Uzay Filmi [G.O.R.A.: A Space Movie]. Dir. Ömer Faruk Sorak. Turkey. 2004.

Gürata, Ahmet. Hollywood in Vernacular: Translation and Cross-Cultural Reception of American Films in Turkey. U of Exeter P, 2007.

Halman, Talat S., and Jayne L. Warner, eds. Ibrahim the Mad and Other Plays. Vol. 1, of An Anthology of Modern Turkish Drama. Syracuse UP, 2008.

Harries, Dan. Film parody. British Film Institute, 2000.
Henderson, Stuart. The Hollywood Sequel: History \& Form, 1911-2010. Bloomsbury, 2017.

Hokkabaz [The Magician]. Dir. Cem Y1lmaz and Ali Taner Baltac1. Turkey. 2006.

The Hunger Games. Dir. Gary Ross. USA. 2012.

Jurassic Park. Dir. Steven Spielberg. USA. 1993.

Kafadar, Cemal "How Dark Is the History of the Night, How Black the Story of Coffee, How Bitter the Tale of Love: The Changing Measure of Leisure and Pleasure in Early Modern Istanbul." Medieval and Early Modern Performance in the Eastern Mediterranean, edited by A. Öztürkmen and E. B. Vitz, Brepols, 2014, pp. 243-69.

Kanzler, Martin. "The Turkish Film Industry: Key Developments 2004 to 2013." A Report by the European Audiovisual Observatory, vol. 3 (2014), pp. 11-18.

Kennedy-Karpat, Colleen. "Self-Adaptation and Transnationality in Marjane Satrapi's Poulet aux prunes (2011)." Adaptation, vol. 8, no. 1 (2015), pp. 68-88.

Klein, Amanda Ann. American Film Cycles: Reframing Genres, Screening Social Problems, and Defining Subcultures. U of Texas P, 2011.

Klein, Amanda Ann, and R. Barton Palmer, eds. Cycles, Sequels, Spin-offs, Remakes, and Reboots: Multiplicities in Film and Television. U of Texas P, 2016.

Kutsal Damacana. Dir. Kamil Aydın and Ahmet Yilmaz. Turkey. 2007.

Kutsal Damacana: Dracoola. Dir Korhan Bozkurt. Turkey. 2011.

Kutsal Damacana: Ittmen. Dir. Korhan Bozkurt. Turkey. 2010.

"The Man Trap." Star Trek: The Original Series. Dir. Gene Roddenberry. 1966.

The Matrix. Dir. The Wachowskis. USA/ Australia. 1999.

McLuhan, Marshall, and Quentin Fiore. "The Medium is the Message." New York, vol. 123, 1967, pp. 126-28.

Newman, Michael Z. Indie: An American Film Culture. Columbia UP, 2011.

Öz, Özlem, and Kaya Özkaracalar. «The Reemergence of İstanbul's Film Industry: A Path- Dependence Perspective.» New Perspectives on Turkey, vol. 56 (2017), pp. 61-85.

Predator. Dir. John McTiernan. USA. 1987.

Propaganda. Dir. Sinan Çetin. Turkey. 1999.

Raw, Laurence. "The Practice of Adaptation in The Turkish Republic: Patriotic Communities." Where Is Adaptation? Mapping Cultures, Texts, and Contexts, edited by Casie Hermansson and Janet Zepernick, John Benjamins, 2018, pp. 197-210.

Recep Ivedik. Dir. Togan Gökbakar. Turkey. 2008.

Recep İvedik 2. Dir. Togan Gökbakar. Turkey. 2009.

Recep Ivedik 3. Dir. Togan Gökbakar. Turkey. 2010.

Şabaniye. Dir. Kartal Tibet. Turkey. 1985.
The Shining. Dir. Stanley Kubrick. USA/ UK. 1980.

Smith, Iain Robert. "“Beam Me up, Ömer': Transnational Media Flow and the Cultural Politics of the Turkish Star Trek Remake." The Velvet Light Trap, vol. 61, no. 1 (2008), pp. 3-13.

Star Wars. Dir. George Lucas. USA. 1977.

Suner, Asuman. "Horror of a Different Kind: Dissonant Voices of the New Turkish Cinema." Screen, vol. 45, no. 4 (2004), pp. 305-23.

The Terminator. Dir. James Cameron. USA. 1984.

Tootsie. Dir. Sydney Pollack. USA. 1982.

Turist Ömer Uzay Yolunda [Ömer the Tourist in Space]. Dir. Hulki Saner. Turkey. 1973.

Üç Arkadaş [Three Friends]. Dir. Memduh Ün. Turkey. 1972.

Vizontele. Dir. Y1lmaz Erdoğan and Ömer Faruk Sorak. Turkey. 2001.

Watchmen. Dir. Zack Snyder. USA. 2009.

The Water Diviner. Dir. Russell Crowe. Australia/USA. 2014.

Yahşi Batı [Mild West]. Dir. Ömer Faruk Sorak. Turkey. 2010.

Yol [The Road]. Dir. Şerif Gören and Yılmaz Güney. Turkey. 1982.

\section{ORCID}

M. Mert Örsler [D

http://orcid.org/0000-0001-8448-8434

Colleen Kennedy-Karpat [C]

http://orcid.org/0000-0003-3915-6478

M. Mert Örsler graduated from Bilkent University with a BA in Communication and Design in 2019. He is currently pursuing graduate study in the Department of Communication, Media, and Film at the University of Calgary. His scholarly interests include national and transnational cinemas, the legacy of international counter-cinemas, and mid-century amateur filmmaking. His work has been published in Visuality of the Anthropocene (Norderstedt, 2019) and the Butler Journal of Undergraduate Research (forthcoming, 2020).

Colleen Kennedy-Karpat holds a $\mathrm{PhD}$ in French from Rutgers University and is an assistant professor in the Department of Communication and Design at Bilkent University, Ankara, Turkey. She is the author of the award-winning monograph Rogues, Romance, and Exoticism in French Cinema of the 1930s (Fairleigh Dickinson, 2013) and co-editor of the collection Adaptation, Awards Culture and the Value of Prestige (Palgrave Macmillan, 2017). Other writing has appeared in Adaptation, the Journal of Popular Film and Television, and several edited volumes, most recently A Companion to the Biopic (Wiley, 2019). Her research focuses on adaptation, genre, stardom, and French national cinema. 